\title{
Investigating the effect of tax costs on accounting conservatism: Evidence from Tehran Stock Exchange
}

\author{
Mohammad Reza Asgari ${ }^{\mathrm{a}}$ and Mohammad Ali Behpouri ${ }^{*}$
}

${ }^{a}$ Assistant Professor, Department of Management, Rey Branch, Islamic Azad University (IAU), Rey, Iran ${ }^{b}$ M.Sc. Student, Department of Management, Naragh Branch, Islamic Azad University (IAU), Naragh, Iran CH R O I C L E A B S T R A C T

Article history:

Received Feb 28, 2013

Received in revised format 19 September 2013

Accepted 23 October 2013

Available online

December 52013

Keywords:

Tax cost

Accounting conservatism

Tehran Stock Exchange
The purpose of this paper is to study the effect of the tax expenses on accounting conservatism on firms listed on Tehran Stock Exchange. In this study to measure the conservatism accruals is used to test the research hypotheses based on the information gathered from 61 firms listed on Tehran Stock Exchange over the period 2004-2009. Findings indicate that the relationship between conservatism accounting and corporate tax burden was positive and significant. In addition, firms with high book-tax conformity had higher motivation to use the conservative accounting to reduce their tax payments.

\section{Introduction}

One of the primary concerns on management of most business units is to choose appropriate policy for tax management (Bliss, 1924; Holthausen \& Watts, 2001; Kim \& Bae, 2006; Bushman \& Piotroski, 2006; Khan \& Watts, 2009). Ahmed et al. (2002) used both a market-based and an accrualbased measure of conservatism to find out whether firms facing more severe conflicts over dividend policy tend to apply more conservative accounting or not. They reported that accounting conservatism was associated with a lower expense of debt after controlling for other determinants of firms' debt expenses. They result is consistent with the notion that accounting conservatism plays an essential role in mitigating bondholder-shareholder conflicts over dividend policy, and in reducing company's debt expenses. Zhang (2008) discussed the contracting advantages of accounting conservatism to lenders and borrowers.

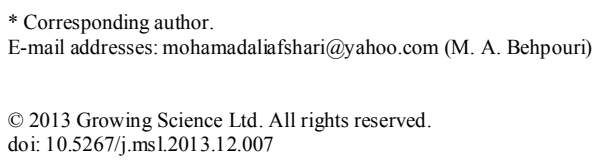


Phillips et al. (2003) evaluated the usefulness of deferred tax expense in determining earnings management. Assuming bigger discretion under GAAP than under tax rules, and assuming managers exploit such discretion to manage income upward in such a way that would not influence current taxable income, then such earnings management would generate book-tax differences, which increase deferred tax expense.

Basu (1997) interpreted conservatism as resulting in earnings representing 'bad news' faster than 'good news'. This interpretation states systematic differences between bad and good news periods in the timeliness and persistence of earnings. Basu reported that negative earnings changes were less persistent than positive earnings changes. Earnings response coefficients (ERCs) were also higher for positive earnings changes than for negative earnings changes.

Beaver and Ryan (2005) developed a model, which captures the distinct natures and interactions between conditional and unconditional conservatism. They explained that under conditional conservatism, book value was written down under sufficiently adverse circumstances, but not up under favorable circumstances. Francis et al. (2003) investigated the relationship between the costs of equity capital and different attributes of earnings such as timeliness and conservatism.

Givoly and Hayn (2000) documented changes in the patterns of earnings, cash flows, identified a number of measures of reporting conservatism and investigated accruals in the absence of a generally accepted definition of conservatism. These measures depend on the accumulation of non-operating accruals, the timeliness of earnings with in terms of bad and good news, characteristics of the earnings distribution and the market-to-book ratio. The patterns were consistent with an increase in conservative financial reporting over time.

Pae et al. (2004) performed an empirical investigation and found that earnings conservatism was negatively associated with balance sheet conservatism. The negative link between earnings conservatism and balance sheet conservatism was primarily due to the accrual component of earnings, not the operating cash flow component of earnings. Penman and Zhang (2002) investigated accounting conservatism, the quality of earnings, and stock returns. They stated that when a firm practices conservative accounting, changes in the amount of its investments could influence the quality of its earnings. Growth in investment may reduce reported earnings and it can create reserves, reducing investment may also release the reserves and consequently increase earnings. They reported that these measures could predict differences in future return on net operating assets relative to current return on net operating assets.

Ryan (2006) provided some guidance for empiricists interested in computing conditional conservatism and in interpreting relationship with those measures with variables of interest. The study provided four specific suggestions for forecasting asymmetric timeliness and for interpreting it as a tool for conditional conservatism. According to Watts (2003), conservatism can be defined as the differential verifiability needed for recognition of profits versus losses.

Nikolaev (2010) used a sample of over 5,000 debt issues to examine whether firms with more extensive use of covenants in their public debt contracts preserve timelier recognition of economic losses in accounting earnings or not. Covenants normally govern the transfer of decision-making, control necessary rights from shareholders to bondholders when a firm reaches financial distress, and thereby limit managers' capabilities to expropriate bondholder wealth. Covenants are anticipated to constrain managerial opportunism, however, only if the accounting system understands economic losses in earnings in a timely fashion. Therefore, the demand for timely loss recognition needs to increase with a contract's reliance on covenants. Nikolaev (2010) reported evidence that reliance on covenants in public debt contracts was positively associated with the degree of timely loss recognition and presented some evidence that the presence of prior private debt mitigated this relationship. 


\section{The proposed study}

The purpose of this paper is to study the effect of the tax expenses on accounting conservatism on firms listed on Tehran Stock Exchange. In this study to measure the conservatism Accruals is used to test the research hypotheses based on the information gathered from 61 firms listed on Tehran Stock Exchange over the period 2004-2009. The dependent variable is accounting conservatism (UC), which is calculated as follows,

$U C=\left(-\frac{1}{3}\right) \sum_{n=0}^{2}\left(\frac{\mathrm{PTI}_{\mathrm{t}-\mathrm{n}}+\mathrm{DEP}_{\mathrm{t}-\mathrm{n}}-\mathrm{CFO}_{\mathrm{t}-\mathrm{n}}}{T A_{t-n}}\right)$,

where PTI represents net profit before tax, DEP denotes the cost of depreciation, $C F O$ is the operating cash flow and finally $T A$ is the total assets. The proposed study of this paper considers the following regression model to test the first hypothesis of the survey,

$U C_{i, t}=\beta_{1}+\beta_{2}$ ETR $_{i, t}+\beta_{3}$ StdROA $_{i, t}+\beta_{4}$ LEV $_{i, t}+\beta_{5}$ PROA $_{i, t}+\beta_{6}$ Size $_{i, t}+\beta_{7}$ SaleG $_{i, t}+\varepsilon_{i, t}$,

where ETR is the effective tax rate, StdROA represents standard deviation of return of assets, $L E V$ denotes leverage ratio, PROA states probability of return of assets, Size is the size of the firm and Sale $G$ denotes the sales growth. In addition, the study uses the following regression model to test the second hypothesis of the paper,

$U C_{i, t}=\beta_{1}+\beta_{2} \operatorname{ETR}_{i, t}+\beta_{3} \operatorname{Corr}(B T) \times E T R+\beta_{4} \operatorname{StdROA}_{i, t}+\beta_{5} \operatorname{LEV}_{i, t}+\beta_{6} \operatorname{PROA}_{i, t}+\beta_{7}$ Size $_{i, t}+\beta_{8}$ SaleG $_{i, t}+\varepsilon_{i, t}$,

where $\operatorname{Corr}(B T)$ is the burden of tax.

For the proposed study of this paper, the selected firms must have the following criteria,

1. They all must the same fiscal calendar ending March.

2. They were not permitted to have any change on their fiscal year.

3. They must have profitable and eligible for tax payment.

4. No holding or financial firm was permitted for survey.

5. All necessary information must be available.

There are two hypotheses associated with the proposed study as follows,

1. There is a meaningful relationship between accounting conservatism and financial burden of Tax.

2. There is a meaningful relationship between accounting conservatism and the consistency of accounting profit and taxable revenue.

\subsection{Descriptive information}

Table 1 demonstrates the summary of some basic statistics associated with our study. As we can observe from the min and max of the data, there are not big deviations among the data. 
Table 1

The summary of some basic statistics

\begin{tabular}{|c|c|c|c|c|c|c|}
\hline Variable & Mean & Standard & Min & Max & Skewnes & Kurtosis \\
\hline Conservative & -0.0538 & 0.0616 & -0.2335 & 0.1254 & 0.1043 & 0.0185 \\
\hline ETR & 0.2885 & 0.789 & 0 & 7.1251 & 5.3398 & 3.5076 \\
\hline Compatibility of accounting taxable & 0.5319 & 0.5468 & -0.9492 & 1 & -1.2289 & 0.3856 \\
\hline StdROA & 0.019 & 0.0191 & 0 & 0.1302 & 2.0872 & 5.9383 \\
\hline LEV & 0.6306 & 0.1584 & 0.1803 & 0.9325 & -0.5055 & -0.4006 \\
\hline PROA & 0.1911 & 0.1336 & 0.0105 & 0.7001 & 1.2422 & 1.6553 \\
\hline Size & 12.631 & 1.2664 & 9.4705 & 15.792 & 0.015 & -0.2703 \\
\hline SaleG & 0.2107 & 0.3524 & -0.9052 & 3.8387 & 4.3719 & 3.0677 \\
\hline
\end{tabular}

\subsection{Hausman and Chow test}

In order to choose between random effect and fixed effect as well as choosing between panel and pooled data we need to perform Hausman and Chow tests and the results are summarized in Table 2 as follows for the first model of the survey.

Table 2

The summary of Hausman and Chow tests

\begin{tabular}{ccccc}
\hline Test & Statistics & Value & df & P-Value \\
\hline Chow & F-value & 3.05 & $(60,295)$ & 0.000 \\
Hausman test & Chi-Squre & 18.843 & 6 & 0.002 \\
\hline
\end{tabular}

Based on the results of Table 2, we understand that we could use panel data and fixed effect to perform regression analysis. Table 3 demonstrates the results of these two tests on the second model.

Table 3

The summary of Hausman and Chow tests

\begin{tabular}{ccccc}
\hline Test & Statistics & Value & df & P-Value \\
\hline Chow & F-value & 10.185 & $(60,295)$ & 0.000 \\
Hausman test & Chi-Squre & 21.108 & 6 & 0.023 \\
\hline
\end{tabular}

The results of Table 3 also confirm that we need to used fixed effect along with panel data.

\section{The results}

In this section, we present details of our survey on testing various hypotheses of the survey. The implementation of this survey has used Eviews to perform the regression model.

\subsection{Testing the first hypothesis}

We first present details of testing the first hypothesis of the survey. The first hypothesis examines the relationship between accounting conservatism and financial burden of Tax.

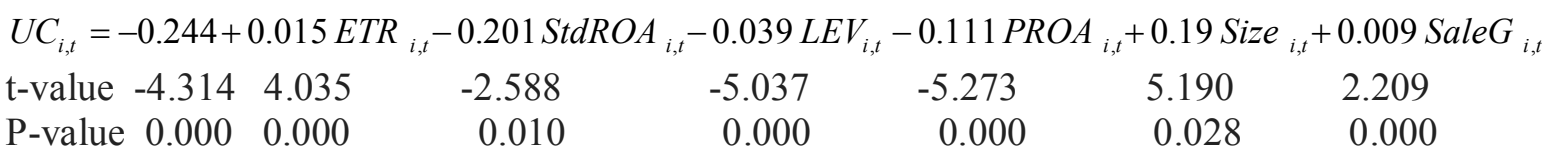

Adjusted R-Square $=0.684 \mathrm{~F}=10.688($ Sig. $=0.000)$ Durbin-Watson $=1.99$

As we can observe from the results of regression analysis, ETR is statistically significant and we can confirm the first hypothesis of the survey.

\subsection{Testing the second hypothesis}

The second hypothesis of this survey is associated with the relationship between accounting conservatism and the consistency of accounting profit and taxable revenue. 


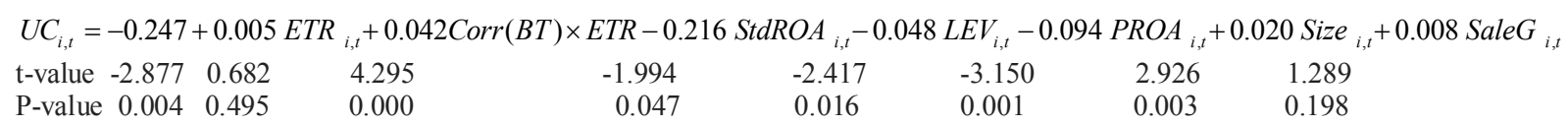

Adjusted R-Square $=0.712 \mathrm{~F}=11.902($ Sig. $=0.000)$ Durbin-Watson $=1.93$

As we can observe from the results of regression analysis, the coefficient of $\operatorname{Corr}(B T) \times(B T)$ is statistically significant. Therefore, the second hypothesis of the survey has been confirmed. In other words, the motivation behind conservatism is to reduce the difference between taxable profit and accounting profit.

\section{Conclusion}

The purpose of conservatism is to detect unpleasant incidents, take necessary actions against unwelcome issues, predict good incidents, and take advantage of the pleasant outcomes. In this paper, we have presented an empirical investigation to study the relationship between accounting conservatism and financial burden of Tax as well as the relationship between accounting conservatism and the consistency of accounting profit and taxable revenue. The proposed model of this paper has been applied on selected firms from Tehran Stock Exchange and the results have confirmed both hypotheses of the survey.

\section{Acknowledgement}

The authors would like to thank the anonymous referees for constructive comments on earlier version of this paper.

\section{References}

Ahmed, A. S., Billings, B. K., Morton, R. M., \& Stanford-Harris, M. (2002). The role of accounting conservatism in mitigating bondholder-shareholder conflicts over dividend policy and in reducing debt costs. The Accounting Review, 77(4), 867-890.

Basu, S. (1997). The conservatism principle and the asymmetric timeliness of earnings. Journal of Accounting and Economics, 24(1), 3-37.

Beaver, W. H., \& Ryan, S. G. (2005). Conditional and unconditional conservatism: concepts and modeling. Review of Accounting Studies, 10(2-3), 269-309.

Bliss, J. H. (1924). Management Through Accounts. Ronald Press Company.

Bushman, R. M., \& Piotroski, J. D. (2006). Financial reporting incentives for conservative accounting: The influence of legal and political institutions. Journal of Accounting and Economics, 42(1), 107-148.

Francis, J., LaFond, R., Olsson, P., \& Schipper, K. (2003). Costs of capital and earnings attributes. Available at SSRN 414125.

Givoly, D., \& Hayn, C. (2000). The changing time-series properties of earnings, cash flows and accruals: Has financial reporting become more conservative?. Journal of Accounting and Economics, 29(3), 287-320.

Holthausen, R. W., \& Watts, R. L. (2001). The relevance of the value-relevance literature for financial accounting standard setting. Journal of accounting and economics, 31(1), 3-75.

Kim, J. O., \& Bae, G. S. (2006). Conservatism and corporate income taxes. Korean Journal of Taxation research, 23, 79-103.

Khan, M., \& Watts, R. L. (2009). Estimation and empirical properties of a firm-year measure of accounting conservatism. Journal of Accounting and Economics, 48(2), 132-150.

Nikolaev, V. V. (2010). Debt covenants and accounting conservatism. Journal of Accounting Research, 48(1), 51-89.

Pae, J., Thornton, D., \& Welker, M. (2004). The link between earnings conservatism and balance sheet conservatism. Queen's Üniversitesi Working Paper. 
Penman, S. H., \& Zhang, X. J. (2002). Accounting conservatism, the quality of earnings, and stock returns. The Accounting Review, 77(2), 237-264.

Phillips, J., Pincus, M., \& Rego, S. O. (2003). Earnings management: New evidence based on deferred tax expense. The Accounting Review, 78(2), 491-521.

Ryan, S. G. (2006). Identifying conditional conservatism. European accounting review, 15(4), 511525.

Watts, R. L. (2003). Conservatism in accounting part I: Explanations and implications. Accounting horizons, 17(3), 207-221.

Zhang, J. (2008). The contracting benefits of accounting conservatism to lenders and borrowers. Journal of Accounting and Economics, 45(1), 27-54. 